DOI: $10.15587 / 2312-8372.2019 .180895$

Mel'nick V., Shybetskyy $\mathbf{V}$.

\section{APPLICATION OF CASSINI OVALS FOR THE FORMATION OF THE 24-HOUR LIGHT ATTENTION OF THE RUNWAY}

Об’єктом досліджень слугує процес забезпечення цілодобової відповідності виконання технічних характеристик освітлення зльотно-посадочної полоси аеродинамічних технологій. Пояснюється наявність виникнення за цих умов дифузного за структурою прощесу тепловіддачі робочого тіла та світлового випромінювання.

Одним з найбільш проблемних місць є складність виготовлення і достатньо велика матеріалоємність вольфрамового тіла розжарювання і подальший контроль відповідності тіла розжарювання вимогам овалів Кассіні.

В ході дослідження здійснювався математичний аналіз алгебрайчних кривих четвертого порядку, які мають форму «вісімки» овала Кассіні $і$ являють собою узагальнення окремого випадку - лемниками Бернуллі «квітка Бернуллі». Овали Кассіні у формі «вісімки» утворюють геометричне місце точок, добуток відстані яких до двох фіксованих точок, фокусів залишається незмінним. Проводився аналіз відповідності перевірки необхідної дифузної структури тепловіддачі робочого тіла і породженою нею світловою гамою, що не має місце у відомих конструкиіях ламп розжарювання.

Аналізується доцільність використання в сигнальних вогнях зони приземлення на злітно-посадочних смугах вольфрамового тіла розжарювання у вигляді струмопровідного «овалу Кассіні». Звертається увага на можливість формування дифузійної структури теплового потоку і світлового випромінювання. Пояснюються перспективи підвищення надійності і довговічності освітлення сигнальних вогнів злітно-посадкової рамки. Обгрунтовуються принщипи вибору масогабаритних характеристик робочого тіла розжарювання сигнальних вогнів.

Отримані додатково дві форми овалів Кассіні із початковою вимогою, що виконується, незмінності величини добутку, зокрема, деформований всередині вихідний овал Кассіні, а також випадок розпадання вихідного овалу Кассіні на два автономних овали навколо фокусів.

Розігрітий вольфрамовий струмопровідний «овал Кассіні» випромінює у всіх напрямках навколишнього простору дифузні за структурою теплові і світлові потоки. Завдяки цьому світлові трикутники в площині «овалу Кассіні», у своїй сукупності, окреслять мозаїку випромінюючих елементів однакової яскравості i забезпечать таким чином суиільне випромінююче яскраве світло у вигляді овальної пластини.

Ключові слова: зльотно-посадочна смуга, овали Кассіні, електрична лампа розжарювання, алгебраїчні криві четвертого порядку.

Copyright (C) 2019, Mel'nick V., Shybetskyy V. This is an open access article under the CC BY license (http://creativecommons.org/licenses/by/4.0)

\section{Introduction}

Depending on the class of aircraft served by runways can be unpaved or with artificial turf (concrete, asphalt, metal, etc.). Runways, as a rule, are equipped with day and night landmarks, signal and restrictive lights (light-signal system of an airfield, or a place of mobile basing). They can also be equipped with aerodrome emergency braking devices (Fig. 1).

According to the certification requirements of Ukrainian civil aerodromes, it is permitted, in some cases, not to equip the runway with special equipment for takeoff and landing level. At the same time, airfields can

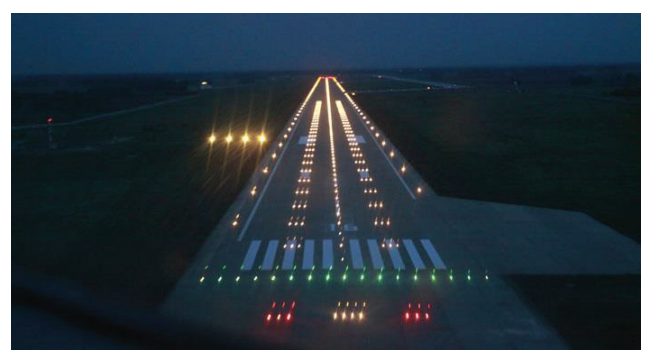

a

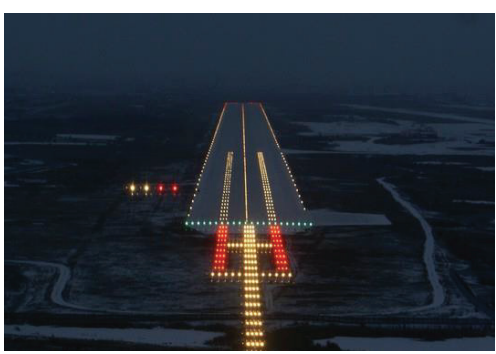

$b$
Fig. 1. Runways: a - runway; $b$ - airfield take-off-signal system 
Particular distinctive properties are characteristic for runways of hypersonic aircraft with ramjet engines, primarily in a mobile take-off and landing design.

Runways can be fundamentally different, both in their area, for example, from $300 \mathrm{~m}$ in length and $10 \mathrm{~m}$ in width, in considerable length - almost $6 \mathrm{~km}$ in length and $80 \mathrm{~m}$ in width (Gaviao-Peixotu, Brazil), and logistics. Small runways are used for light and ultralight aircraft. So, for example, for small-engine aviation, trikes, etc. $100 \mathrm{~m}$ of run-up is enough at the time of take-off and as much during landing. The largest runways are being built at major international airports and aircraft factories [3].

Therefore, it is relevant to study the effectiveness and continuity of the signal lights of airfields and mobile-based aircraft systems, regardless of meteorological conditions and time of day.

\section{The object of research and its technological audit}

The object of research is the process of ensuring 24-hour compliance with the technical characteristics of the illumination of the runway of aerodynamic technologies. The existence of, under these conditions, the diffusion in structure of the heat transfer process of the working fluid and light radiation is explained. It is emphasized that under these conditions, the danger of violating the integrity and working quality of the body of the incandescent means of signal lights disappears. It is noted that the use of Cassini ovals can significantly reduce the evaporation level of the tungsten of the working fluid, to protect the thinning of the filament material with its subsequent destruction and premature failure of the light bulb as a whole.

A certain drawback of the proposed technical solution is the difficulty of manufacturing and a sufficiently large material consumption of the tungsten incandescent body and subsequent control of the compliance of the incandescent body with the requirements of the Cassini ovals.

\section{The aim and objectives of research}

The aim of research is the process of creating a diffuse structure of 24-hour lighting of the aerodynamic technology runway.

To achieve this aim, it is necessary to complete the following tasks:

1. To reduce the technological complexity of manufacturing an incandescent body.

2. To increase the technological ability of an incandescent lamp for the entire period of use.

3. Maintaining the level of the initial physical and mechanical characteristics of an incandescent lamp during the entire period of operation.

4. To carry out the construction of a mathematical model and analysis of the investigated phenomena.

\section{Research of existing solutions of the problem}

For safe mode of takeoff of the aircraft or its landing on the runway at night, or in the early hours of the day, as well as with insufficient visibility, light-signaling equipment is used.

The main types of light-signaling equipment (LSE) include: low-intensity lights (LIL) and high-intensity lights (HIL) [4].

High-intensity lights on the runway are a white light stripe - strobes - 500-700 m long. When approaching, the pilot uses gates to visually control the position of the fuselage relative to the longitudinal axis of the runway. The runway threshold (end) is marked by an almost continuous line of green lights perpendicular to the strobe line.

The center line of the runway is also indicated by white lights. The edges of the runway are yellow. The aerodrome's light-signaling equipment is divided into groups of lights, which are arranged in a certain sequence, as well as easily recognizable when the pilot makes contact with the ground.

The following groups of signal lights are used [5]:

- approach lights of steady and pulsed radiation;

- lights of light horizons;

- entrance lights;

- lights of the landing site;

- restricting fire;

- landing zone lights;

- side lights and landing zone lights;

- glide lights;

- landing lights;

- lights of the final braking strip;

- axial lights;

- lights of fast rise;

- side and axle taxi lights;

- stop lights;

- warning lights;

- restrictive lights;

- aerodrome light indicators.

The system of landing lights, taking into account the peculiarities of mobile-based aircraft, is mainly designed to fulfill the same landing features as at airfields. An additional fact, unlike soil ones, is that it must also take into account the dynamics and kinematics of mobile landing aids.

Yes, by the way, carrier-based aviation (tactical and strategic) must be based and take off from the carrier's waist at any time of the day and in any weather situation. This feature significantly complicates both the mooring process and the deck launch (Fig. 2) [6].

Landing zone lights are used to mark the landing place on the runway to facilitate landing under adverse weather conditions and visibility. The lights are installed in two rows parallel to the runway axis at a distance of $900 \mathrm{~m}$ from the threshold of the runway. They emit white light. Uninterrupted operation of landing lights is provided by airfield incandescent lamps [7].

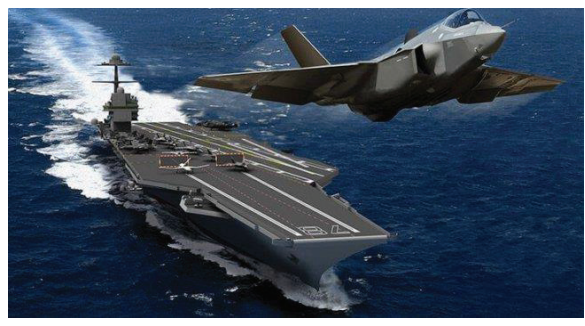

a

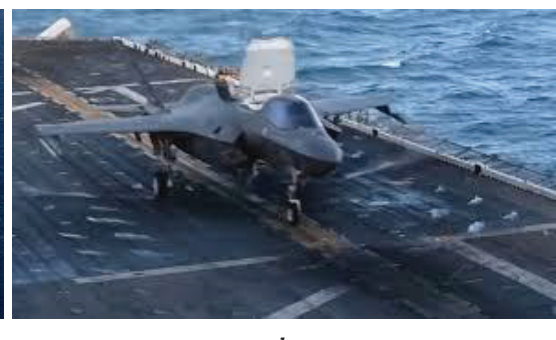

$b$
Fig. 2. Carrier-based aviation:

$a$ - deck launch of an aircraft from a mobile-based runway; $b$ - mobile-based runway 
An incandescent lamp consists of a glass bulb, a tungsten filament body and a cap. In the shape of a bulb, airfield incandescent lamps are drop-shaped, pear-shaped, spherical, ring-shaped and cylindrical. The bases of incandescent lamps are threaded and pin.

An incandescent tungsten body in incandescent lamps is made of a tungsten wire in the form of a twisted filament [8]. In order to reduce additional heat loss, a double filament is sometimes called a bifilament. When current flows, the filament heats up and, reaching a temperature determined by the Passport, emits light energy from the outside. The higher the temperature of the tungsten incandescent body, the more powerful the light flux it emits. Under the influence of high temperature, the tungsten incandescent body evaporates over time [9, 10].

Tungsten particles incandescent to a high temperature slowly settle on the inner surface of a glass bulb of an incandescent lamp and cover it with a dark layer, and the tungsten incandescent body, accordingly, is thinner and burns out over time. To reduce the level of evaporation of the tungsten in the incandescent body, the glass bulb is filled with an inert gas - a mixture of $86 \%$ argon and $14 \%$ nitrogen. But under these conditions, heat losses inevitably increase due to the existing thermal conductivity and convection of the gas mixture of the lamp [11, 12]. For this reason, inert gas is usually filled with relatively powerful lamps, while incandescent lamps with a power of 15, 25 and $50 \mathrm{~W}$ for a voltage of $110-127 \mathrm{~V}$ and 25,40 and $60 \mathrm{~W}$ for a voltage of $220 \mathrm{~V}$ are made of vacuum glass cylinders.

Incandescent lamps designed for high power or low voltage are made with a larger diameter of the tungsten incandescent body than light sources of lower power or high voltage. For this reason, they provide a large current flow and have a higher incandescent temperature and increased light output. Based on this, incandescent lamps for landing searchlights and light beacons are made for low voltage [13].

When the lamp is burning, tungsten vaporization and thinning of the incandescent filament lead to an increase in lamp resistance, a decrease in current and light output of the lamp. The lamp life is directly related to light output the higher the light output, the higher the temperature of the filament and the faster the tungsten evaporates [14].

In aerodrome installations with chops and lens optics, in which it is advisable to use lamps with an incandescent body of a higher brightness, the light output becomes crucial, even to the detriment of the lamp life. In obstruction lights, where frequent lamp changes are difficult, it is necessary to have a long lamp life, not even in favor of light output.

Searchlight incandescent lamps have small dimensions of the incandescent body, but, at the same time, a large overall brightness. Their light distribution characteristics are made in such a way that most of the luminous flux of the lamp falls on the reflector. To achieve small scattering angles in the vertical plane and a large scattering angle in the horizontal plane, lamps with a tungsten filament body located across the longitudinal axis of the lamp are used. Incandescent lamps with a vertical tungsten filament are used in lights with a large viewing angle. One of the varieties of incandescent lamps is halogen lamps, which are widely used in lights of the advanced type of lighting systems for landing, as well as in the lights of aircraft parking lots.
All fires in the landing zone to a greater or lesser extent contribute to the safety of aerodrome technologies. Let's focus on one of the most important ground systems of signal lights - landing zone lights.

Landing zone lights are set at a distance of $900 \pm 30 \mathrm{~m}$, at the start of the runway threshold, according to a pattern that is formed by pairs of linear lights located in pairs symmetrically to the center line of the runway. The transverse distance between the internal lights of a pair of linear lights is equal to the transverse distance selected for the markings of the landing zone. In the longitudinal direction, linear fires are discrete-continuous linear fires symmetrical with respect to the longitudinal axis of the runway and form a kind of safe corridor for the aircraft to land. The distance between the linear lights is $1 / 2$ the interval between the side lights of the runway (not more than $30 \mathrm{~m}$ ), or the interval between the side lights of the runway (not more than $60 \mathrm{~m}$ ) [15].

Linear fires of the landing zone have those significant drawbacks that, under certain conditions, can even cause a violation of the landing technology. It is about the influence of some harmful factors, of which the most significant factor is the factor of ensuring a constant saturated light situation under any meteorological conditions, as well as during the day. However, the body does not ensure compliance with the requirements for uninterrupted operation of an incandescent lamp.

A radical way out of an undesirable situation is the use of incandescent lamps with a working body in the form of a Cassini oval for linear lights, which will provide more reliable and durable operation of the main element the incandescent body. And besides, it will form uniform illumination in the devices of linear lights of the landing zone, as a result of the existing diffuse structure of the thermal and light radiation of the Cassini ovals.

\section{Methods of research}

The technical result from the use of a general-purpose incandescent lamp «Cassini» is provided by the fact that the tungsten incandescent body is made in the form of an «eight-shaped» conductive «Cassini oval». This provides a constant value of the product of the distance of an arbitrary point $\mathrm{M}$ of the «Cassini oval» in two focuses $f_{1}$ and $f_{2}$. Connecting the focuses $f_{1}$ and $f_{2}$ a straight line, let's obtain a triangle $f_{1} M f_{2}$ in the plane of the «Cassini oval». The condition of a constant value of the product of lines $f_{1} M$ and $f_{2} M$ can be further considered as a requirement of a constant size of a triangle $f_{1} M f_{2}$ in the plane of the «Cassini oval». If this representation of the analysis of the phenomenon is repeated for all points of the «Cassini oval», let's obtain an infinite number of triangles which planes are equal to each other. The heated tungsten conductive «Cassini oval» emits heat and light fluxes diffuse in structure in all directions of the surrounding space. The given light triangles in the plane of the «Cassini oval», in their totality, will designate a mosaic of radiating elements of the same brightness and thus create a continuous emitting bright light in the form of an oval plate.

The Cassini general-purpose incandescent lamp proposed in the work belongs to light sources that operate on the principle of thermal radiation and contains:

- glass bulb 1 (Fig. 3);

- tungsten incandescent body in the form of a con-

ductive «Cassini oval» 2 (Fig. 3, 4); 
- molybdenum hooks 3;

- electrodes 4;

- glass rod (cane) 5;

- lens 6;

- hollow glass cylinder 7;

- blade 8 - the upper part of the cylinder, in which the cane 5, electrodes 4 and the exhaust tube 9 are connected;

- opening in the blade 10 , through which the lamp

is pumped out;

- metal cup of the lamp base 11, to which one of the electrodes 4 is soldered;

- brass contact washer 12 , to which the second electrode 4 is soldered;

- molten glass 13, which fastens the brass contact washer 12 with a glass base 11 ;

- mastic 14, with which the lamp base 11 is connected to the bulb 1 of the lamp (Fig. 3).

The tungsten incandescent body is made in the «eightshaped» form of the conductive «Cassini oval» (Fig. 5).

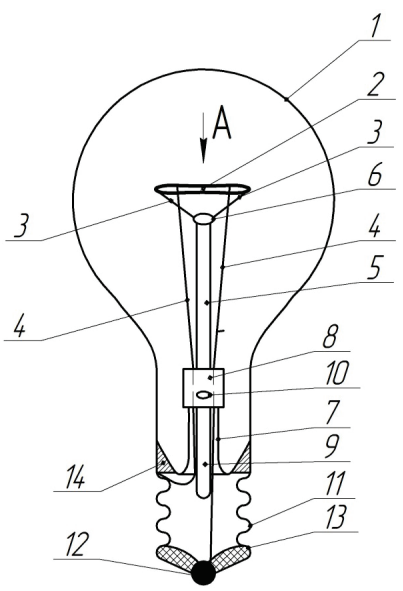

Fig. 3. General-purpose incandescent lamp «Lassini» in cross section with an incandescent body in the form of a tungsten conductive «Cassini oval»

\section{A}

lenlarged)

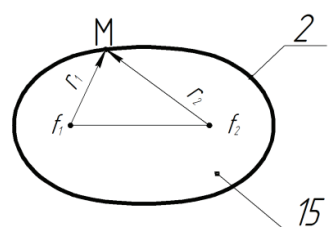

15

Fig. 4. A tungsten incandescent body in the form of a conductive «Lassini oval» (enlarged)

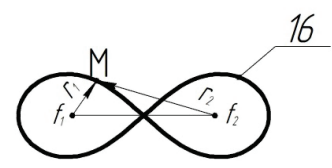

Fig. 5. The main element of the "eight-shaped» form of the Cassini oval

The work of the proposed general-purpose incandescent lamp «Cassini» is as follows. A general-purpose incandescent lamp is a light source that emits a luminous flux as a result of the voltage of a conductor of refractory metal. The «Cassini oval» made of refractory metal - tungsten serves as an incandescent body. In a glass bulb 1 filled with an inert gas (krypton, nitrogen, argon), an incandescent body 2 is placed. Inert gas serves as an effective protection of the material of the incandescent body 2 . In the absence of inert gas in the flask 1, the incandescent body 2 instantly turns into oxide. For incandescent lamps of low power $(25 \mathrm{~W})$ and less, vacuum vessels are used, do not need to be filled with inert gas. Thus, the glass bulb 1 prevents the destructive effect of the surrounding atmosphere on the surface of the tungsten incandescent body 2 .

As it is known, the principle of operation of a generalpurpose incandescent lamp is based on the phenomenon of heating a conductive element when an electric current passes through it. An incandescent tungsten body 2, when an electric current passes, is heated to a high temperature, as a result of which it emits light. The luminous flux emitted by incandescent body 2 , from the outside is close to natural, daylight, therefore, does not cause discomfort during prolonged use. Only a small fraction of the energy consumed from the network is converted by an incandescent lamp into visible light, the bulk of the energy of which is consumed by heating the incandescent body 2 and emitting light in a range invisible to the human eye. In order to increase the efficiency of an incandescent lamp, it is necessary to increase the temperature of the incandescent body 2, but not more than the melting temperature of the material of the incandescent body 2 . The melting temperature, which is used in incandescent materials, is:

- tungsten $-3410{ }^{\circ} \mathrm{C}$;

- osmium - $3045{ }^{\circ} \mathrm{C}$.

The operating temperature of a tungsten incandescent body is usually within $2700-3000 \mathrm{~K}$. The maximum efficiency of an incandescent lamp is approximately $15 \%$ and is achieved at a temperature of a tungsten filament filament $-3400 \mathrm{~K}$, at a nominal temperature of a tungsten filament filament it is equal $2700 \mathrm{~K}$, that is $4-5 \%$. With increasing temperature, the efficiency increases, at the same time, the durability of the filament material decreases. So, at a temperature $2700 \mathrm{~K}$ in the life of an incandescent lamp is about 1000 hours, and at a temperature $3400 \mathrm{~K}$ - only a few hours.

In the inner space 15 of incandescent body 2 in the form of a «Cassini oval» a certain number of «Cassini ovals» are formed, which also correspond to the conditions of existence of the «Cassini oval». They constitute the geometric place of the points in the inner space of the original «Cassini oval», the product of which is the same distance from the focuses $f_{1}$ and $f_{2}$ does not change in magnitude for all points of the «Cassini ovals». It is noteworthy that the initial «Cassini oval» tends to develop in the inner space of the incandescent body 2. It is about the emergence and further increase in the depression of the midpoints of the two large sides of the «eight-shaped» Cassini ovals towards the middle of the line focuses $f_{1}$ and $f_{2}$ of the connection of the focuses (Fig. 5). Let's obtain the lines of «Cassini ovals» 16 , which collide with the line of focuses $f_{1}$ and $f_{2}$, at the same time, it remains invariably present the main property of the original «Cassini oval», namely, constant in magnitude and unchanged relative to the original values of the product 
of the distances of all points of the geometric place of the small «Cassini ovals» to the focuses $f_{1}$ and $f_{2}$ [16]. The constant size of the line areas, the combination of the geometric locations of the points of the «Cassini ovals» will serve as an additional factor for the stable illumination of the internal space of the «Cassini oval» of the incandescent body 2 as a whole, like a powerful ray of light.

\section{Research results}

To obtain the Cassini oval graphs, a program was constructed using the Rath application software Mathcad Prime 4.0 (Fig. 6). To obtain an image of the Cassini ovals on a scale (Fig. 7), functions are explicitly defined between the coordinates $y$ and $x$ for both «positive» and «negative» values. The distance between the focuses $10 \mathrm{~cm}$ is chosen to be the value in (Fig. 7), and the value of the parameter «a» is $0.8 ; 1 ; 1.2 ; 1.4$ half the distance between the focuses.
The distance between the focuses $2 c$, they are located on the axis $O X$, the coordinate origin divides the segment between them in half, then the next equation will set the lemniscate. In rectangular coordinates, the formula has the form:

$$
\left(x^{2}+y^{2}\right)^{2}-2 c^{2}\left(x^{2}-y^{2}\right)=a^{4}-c^{4} .
$$

$$
\begin{array}{ll}
c:=5 \\
a:=1 \cdot c \\
y_{1}(x):=\sqrt{\sqrt{a^{4}+4 \cdot c^{2} \cdot x^{2}}-x^{2}-c^{2}} \\
y_{2}(x):=-\sqrt{\sqrt{a^{4}+4 \cdot c^{2} \cdot x^{2}}-x^{2}-c^{2}} & y_{f}:=0 \\
x:=-15,-14.999 . .15 & x_{f 1}:=5 \quad x_{f 2}:=-5
\end{array}
$$

Fig. 6. Program listing

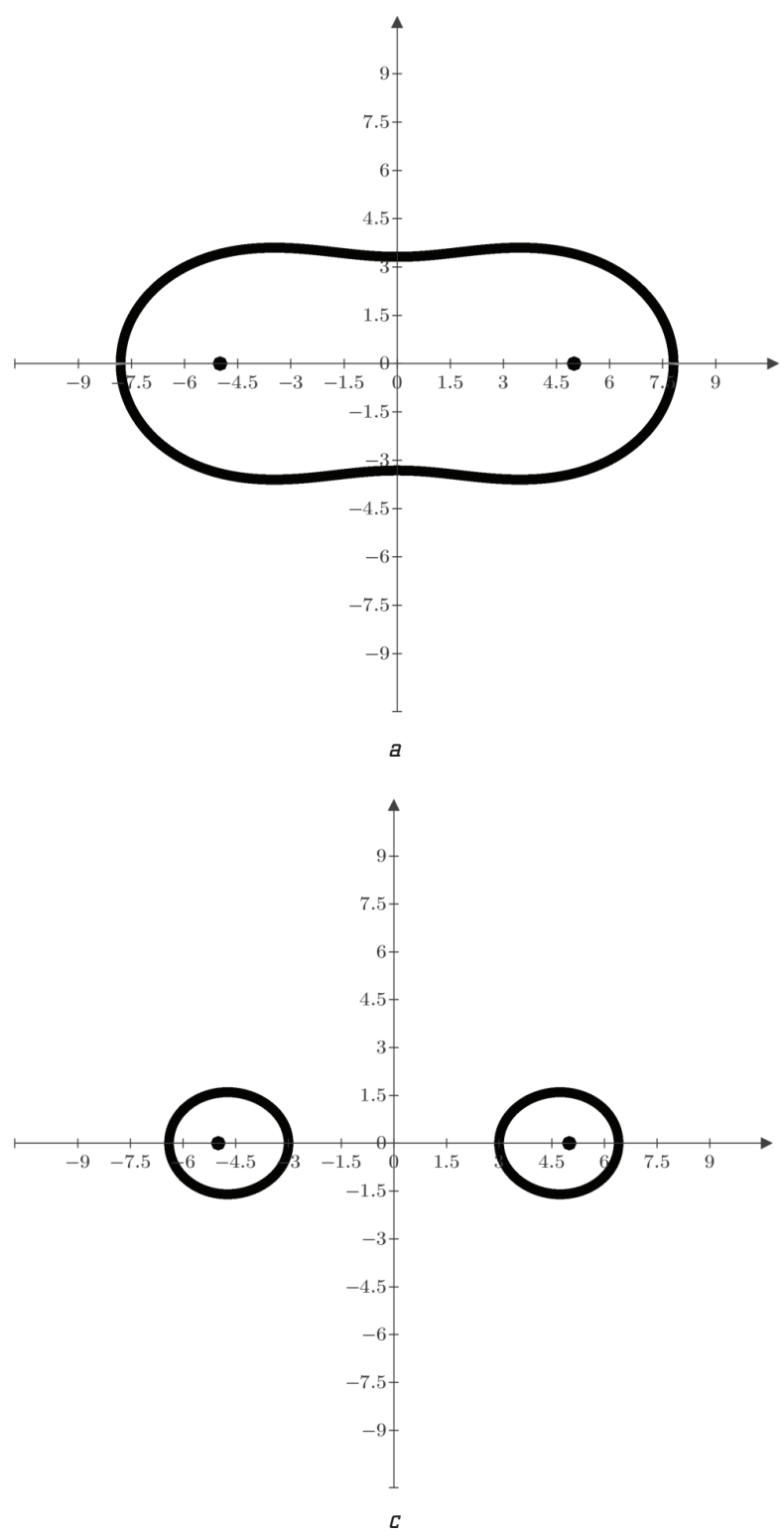

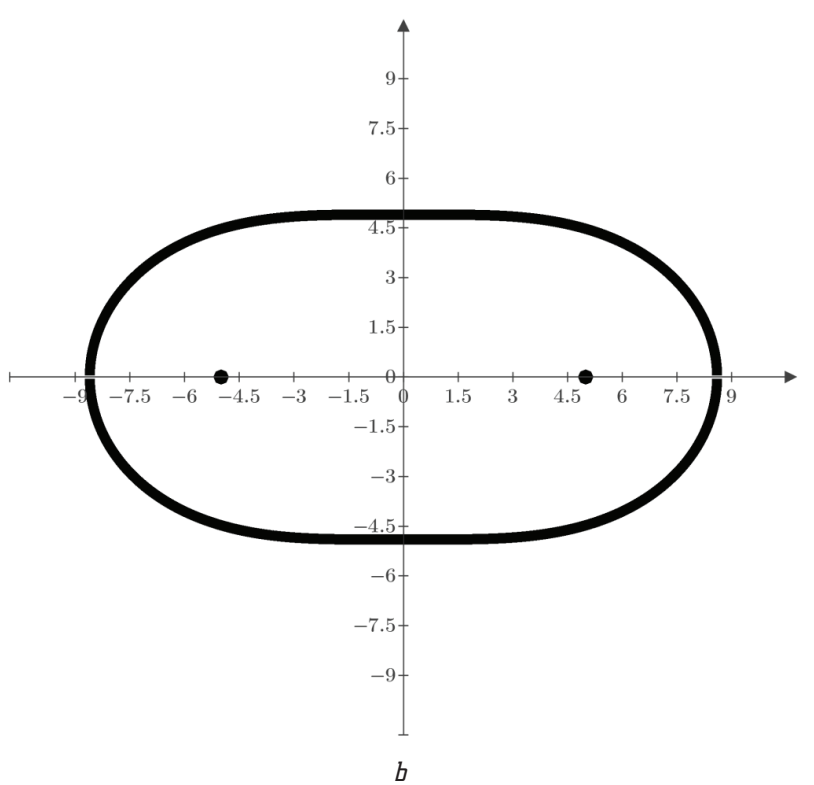

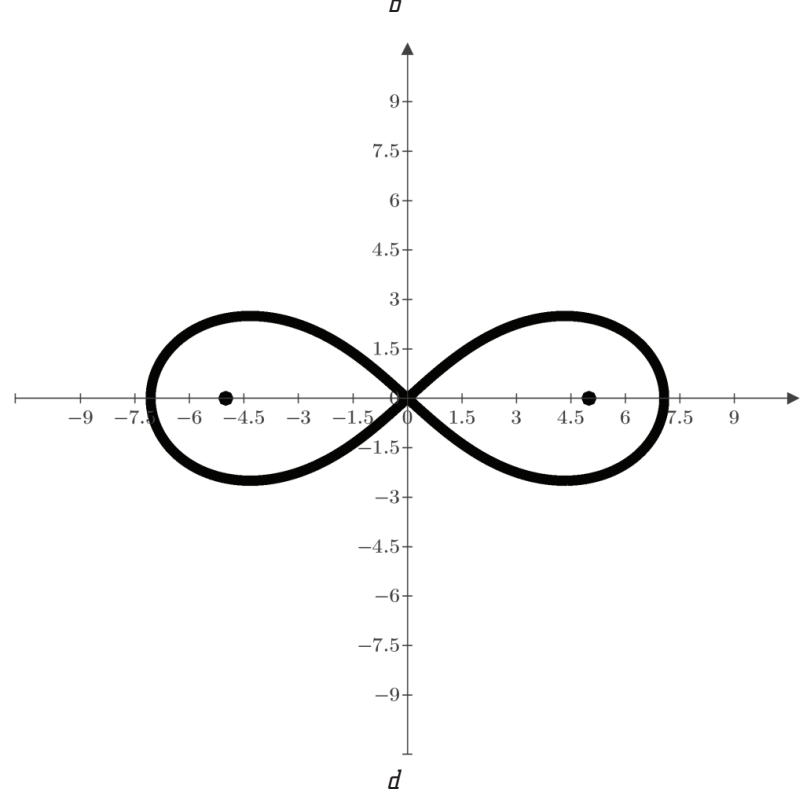

Fig. 7. Graphs of Cassini ovals:

$a$ - parameter $a=1.2 \mathrm{~s} ; b$ - parameter $a=1.4 \mathrm{~s} ; c$ - parameter $a=0.8 \mathrm{~s} ; d$ - parameter $a=1 \mathrm{~s}$, Cassini oval of the «eight-shaped» form 
For an incandescent lamp, it is proposed to choose a graph of the Cassini oval, which has the «eight-shaped» form. A special case of Cassin ovals is a lemniscate, which also gives a geometric place in the «eight-shaped» form and is called a «Bernoulli flower» - the product of the distances from which to two given points (focuses) is unchanged and is equal to the square of half the distance between the focuses. Cassini ovals in the «eight-shaped» form will ensure the integrity of the incandescent working fluid and the initial geometry of the figure eight Cassini oval. Under these conditions, a diffuse structure of the process of heat transfer of the working fluid with subsequent diffuse light radiation is created around the clock. The level of tungsten evaporation of the working fluid is substantially reduced, and the thinning of the material of the incandescent filament with its subsequent destruction and premature failure of the light bulb as a whole is ensured.

\section{SWOT analysis of research results}

Strengths. An original solution to the proposed technical implementation results in the implementation of a working body of an incandescent lamp in the form of conductive Cassini ovals, made, in particular, of tungsten material in the «eight-shaped» form. Such a solution allows, first of all, to obtain a gain in the length of the incandescent body along the body of the signal lamp, which is much higher than that adopted in classical incandescent lamps of a tungsten filament or bifilament, firstly. Secondly, the large mass and length of the incandescent body create a more powerful light shine, on the one hand, on the other hand, they significantly increase the working life of the incandescent body and decisively reduce the level of tungsten evaporation.

Weaknesses. The significant length of the «tungsten eight» of the filament body causes a change in the geometry of the incandescent body and unwanted deflections between the attachment points.

Opportunities. It can be used as a transition curve for rounding of small radius, on railway lines in mountainous areas and on tram tracks. Thus, eight provides a smooth curve, without which the centrifugal force acting on the train would grow sharply, causing inconvenience to passengers. Also in the field of physics, it can be pointed out that the line of the field created by two parallel currents flowing along infinitely long conductors in the plane to them is perpendicular to the Cassini oval in the «eight-shaped» form. Thanks to the solution proposed in the work, it is possible to increase the quality and service life in the signal light means of aerodromes.

The use of the proposed general-purpose incandescent lamp in the «eight-shaped» form of the Cassini ovals will allow the use of lamps on the runways of airfields, including mobile-based runways, around the clock, under any meteorological conditions, for a safer take-off or landing.

Threats. Additional costs will be associated with the need for tight control of the state of the surface of the incandescent body and scale, which are collected on the surface of the glass of the incandescent lamp and will constantly require cleaning. Certain difficulties will arise if it is necessary to replace the incandescent body due to its significant mass-dimensional characteristics.

\section{Conclusions}

1. Manufacturing an incandescent body in the form of a filament or bifilament is quite complex. And on the other hand, it is also not reliable, and limits the possibility of adjusting the effectiveness of its action in terms of the formation of light radiation uniform in structure. The proposed technology for manufacturing an incandescent body in the form of a Cassini oval provides the possibility of forming a diffuse structure of thermal radiation of an incandescent body with the subsequent creation of light radiation that is also diffuse in structure. This is achieved by performing an incandescent body in the form of ovals, which correspond to the initial requirements of a constant product of the distances of the points of the ovals to two fixed points, focuses.

2. The use of a tungsten incandescent body in the «eight-shaped» form of the Cassini ovals will provide the minimum allowable technological level of evaporation of tungsten and the formation of scale.

3. A heated tungsten conductive «Cassini oval» will emit heat and light fluxes diffuse in structure in all directions of the surrounding space. The resulting light triangles in the plane of the Cassini Oval, in their entirety, will denote a mosaic of radiating elements of the same brightness. This creates a solid emitting bright light in the form of an oval plate, which, in turn, will provide output physical and mechanical characteristics of an incandescent lamp.

4. Mathematical modeling shows that, in addition to the eight, two more forms of Cassini ovals were obtained. In particular, the Cassini exit oval, which is deformed inside, as well as the case of the decay of the original Cassini oval into two autonomous ovals around the focuses. «Eight-shaped» Cassini ovals will ensure the integrity of the incandescent working fluid and the original geometry of the «eight» of the Cassini oval of the incandescent lamp and maintaining the product of the distances between the focuses unchanged.

\section{References}

1. Antonov, O. K. et. al.; Bazhan, M. P. (Ed.) (1985). Vol. 4: Elektrod - Kantarydyn. Ukrainska radianska entsyklopediia. Kyiv: Holovna redaktsiia URE, 558.

2. V Zaporozhskom aeroportu zameniat svetosignalnuiu sistemu za 62 milliona (2019). Available at: https://ipne.ws/news/zp/ v-zaporozhskom-aeroportu-zamenyat-svetosignalnuyu-sistemuza-62-milliona/

3. Zlitno-posadkova smuha. Wikipedia. Available at: https:// uk.wikipedia.org/wiki/Злітно-посадкова_смуга

4. Glushkov, G. I., Babkov, V. F., Trigoni, V. E. et. al. (1992) Izyskanie i proektirovanie aerodromov. Moscow: Transport, 463.

5. Vzletno-posadochnaia polosa. Svetosignalnoe oborudovanie. Wikipedia. Available at: https://ru.wikipedia.org/wiki/Взлётнопосадочная_полоса

6. Akymov, O. O., Oliinyk, R. M, Pylypchyk, S. V., Habieva, T. V., Sydko, I. P. (2018). Nove svitlo-tekhnichne obladnannia dlia aerodromiv. Stvorennia ta modernizatsiia ozbroiennia i viiskovoi tekhniky v suchasnykh umovakh. Chernihiv, 36-37.

7. Milashkina, O. V. (2014). Elektrosvetotekhnicheskoe oborudovanie aerodromov. Ulianovsk: UVAU GA(I), 117.

8. Ulmishek, L. G. (1958). Proizvodstvo elektricheskikh lamp nakalivaniia. Moscow-Leningrad: Energiia, 274.

9. Polischuk, D. D., Polischuk, D. Ia. (1983). Pat. SU 1023451 A Elektricheskaia lampa nakalivaniia. MPK: H01K 1/32. No. 3316959. Declareted: 13.07.1981; published: 15.06.1983. Available at: http://patents.su/3-1023451-ehlektricheskaya-lampa-nakalivaniya.html 
10. Uschkamp, G., Meseberg, H. (1995). Zusammenhand Zwischen dem Niveau der Suabehbelcuchtung und dem Verkchrsunfallgeschehen. Licht, 47, 7-8.

11. Abramian, A. A., Sarkisian, A. A., Radko, A. V. (1992). A.s. No. 1714721. Trubchataia galogennaia lampa nakalivaniia s proizvolnym polozheniem goreniia. MPK: H01K 1/28. No. 4653635. Declareted: 22.02.1989; published: 23.02.1992, Bul. No. 7

12. Radko, A. V., Sarkisian, A. A., Martirosian, E. A. (1990). A.s. No. 1543475. Lampa nakalivaniia. MPK: H01K 1/16. No. 4456919. Declareted: 12.05.1988; published: 15.02.1990, Bul. No. 2.

13. Slushkov, A. M., Smirnov, N. N., Pukhin, N. P. (1995). Pat. SU 1834586 A1. Sposob izgotovleniia lampy nakalivaniia. MPK: H01K 1/10. No. 4765195/07. Declareted: 16.10.1989; published: 20.08.1995, Bul. No. 23. Available at: http://patents.su/31834586-sposob-izgotovleniya-lampy-nakalivaniya.html

14. Vugman, S. M., Volkov, V. I. (1980). Gologennye lampy nakalivaniia. Moscow: Energiia, 136.

15. Prokhorov, A. M. (Ed.) (1982). Sovetskii enciklopedicheskii slovar. Moscow: Sovetskaia enciklopediia, 1600.
16. Korobiichuk, I., Mel'nick, V., Karachun, V. (2019). Modeling of voltaic pile surface formation using current-carrying cassini ovals. Engineering Science and Technology, an International Journal, 22 (1), 353-358. doi: http://doi.org/10.1016/j.jestch.2018.08.004

Mel'nick Viktorij, Doctor of Technical Sciences, Professor, Head of Department of Biotechnics and Engineering, National Technical University of Ukraine «Igor Sikorsky Kyiv Polytechnic Institute», Ukraine,e-mail:vmm71@i.ua, ORCID: http://orcid.org/0000-00020004-7218

Shybetskyy Vladyslav, PhD, Associate Professor, Department of Biotechnics and Engineering, National Technical University of Ukraine «Igor Sikorsky Kyiv Polytechnic Institute», Ukraine, e-mail: v.shybetsky@gmail.com, ORCID: http://orcid.org/00000001-5482-0838 